\title{
PENDAMPINGAN BAGI ANAK PENYANDANG THALASEMIA DAN KELUARGANYA
}

\author{
OLEH \\ NURLIANA CIPTA APSARI ${ }^{1}$ \\ ${ }^{1}$ Staf Pengajar Departemen Kesejahteraan Sosial Universitas Padjadjaran
}

(nurlia.apsari@unpad.ac.id)

\begin{abstract}
Abstrak
Thalasemia adalah penyakit genetis yang terdeteksi disaat seseorang masih dalam usia anakanak. Sebagai efek dari penyakit ini, anak tidak dapat terlepas dari perawatan transfusi darah. Perawatan transfusi darah masih merupakan satu - satunya cara mencegah kematian pada anak penyandang thalassemia ini. Bagi anak dan keluarganya, fakta bahwa anak di diagnosa mengidap thalassemia bagaikan mimpi buruk karena beberapa hal, seperti diantaranya adalah ancaman kematian, perawatan transfusi darah se umur hidup anak, dan perubahan bentuk fisik anak yang terlihat jelas. Dampak dari diagnosa thalassemia salah satunya adalah perubahan kehidupan berinteraksi mereka dengan orang lain.
\end{abstract}

\section{PENDAHULUAN}

Thalasemia adalah penyakit genetis yang terdeteksi disaat seseorang masih dalam usia anak-anak. Sebagai efek dari penyakit ini, anak tidak dapat terlepas dari perawatan transfusi darah. Perawatan transfusi darah masih merupakan satu-satunya cara mencegah kematian pada anak penyandang thalassemia ini. Bagi anak dan keluarganya, fakta bahwa anak di diagnosa mengidap thalassemia bagaikan mimpi buruk karena beberapa hal, seperti diantaranya adalah ancaman kematian, perawatan transfusi darah se umur hidup anak, dan perubahan bentuk fisik anak yang terlihat jelas. Dampak dari diagnosa thalassemia salah satunya adalah perubahan kehidupan berinteraksi mereka dengan orang lain.

Disaat anak tiba waktunya untuk mendapatkan rutin transfusi darah setiap bulannya, anak harus berhenti melakukan kegiatan rutinitas yang disenanginya dan menghadapi kesakitan jarum suntik untuk transfusi darah. Jika anak yang telah bersekolah, maka kegiatan kunjungan rutin ke rumah sakit berpotensi mengganggu prestasi akademik anak tersebut. Perubahan fisik akibat dari thalassemia juga berpotensi mengganggu hubungan interaksi anak dengan orang lain. Bagi orang tua anak penyandang thalassemia yang masih awam dengan penyakit ini, mereka akan cenderung mengunci anaknya di rumah 
karena menyadari adanya kelainan fisik pada anak dan khawatir keluarga mendapatkan cemoohan dan ejekan dari masyarakat tempat mereka tinggal. Bagi anak sendiri, disaat menyadari bahwa secara fisik ia berbeda dengan anak pada umumnya, ia akan merasa rendah diri dan mulai menarik diri. Bahkan di beberapa kasus, banyak anak penyandang thalassemia yang dikucilkan oleh temantemannya karena secara fisik ia berbeda dari mereka dan akibat lebih jauh dari dikucilkan tersebut adalah anak berhenti bersekolah sebelum waktunya (Popti, 2015).

\section{PEMBAHASAN}

Pengucilan, ejekan dan diskriminasi bagi anak penyandang thalassemia dan keluarganya berpotensi mengganggu pencapaian kesejahteraan mereka sebagai individu dan menggangu keberfungsian mereka secara sosial. Individu disebut berfungsi secara sosial disaat ia merasakan puas dengan perannya dalam kehidupan, memiliki hubungan yang positif dengan orang lain dan memiliki rasa berharga pada dirinya sendiri (Thackeray, et.al. 1994). Anak penyandang thalassemia dan keluarganya berpotensi memiliki masalah sebagai berikut: pendapatan keluarga yang terganggu karena kebutuhan perawatan medis secara rutin; anak tidak mendapatkan hak pendidikannya yang akan mempengaruhi perkembangan sosial, kognisi, dan emosinya; perasaan terabaikan dari saudara kandung anak penyandang thalassemia; perasaan diantara pasangan orang tua yang tidak terungkapkan, serta masalah pengasuhan anak. Dengan perawatan medis yang dilakukan secara rutin, orang tua tentu harus menyediakan anggaran tersendiri untuk kebutuhan selama anak mendapatkan perawatan medis tersebut. Meskipun biaya rumah sakit mungkin sudah terlindungi oleh asuransi kesehatan, namun masih banyak keperluan lain yang memerlukan dukungan finansial bagi orang tua agar dapat membawa anaknya ke rumah sakit untuk mendapatkan transfusi darah. Mendapatkan pendidikan adalah salah satu hak dasar anak, dan orang tua serta pemerintah wajib memastikan anak mendapatkan hak pendidikannya tersebut. Tingkat pendidikan mempengaruhi kesempatan anak-anak penyandang thalassemia mendapatkan pekerjaan dengan pendapatan yang lebih tinggi (Brown \& Sessions, 1999). Oleh karena itu, memenuhi hak pendidikan pada anak penyandang thalassemia menjadi sangatlah penting agar disaat mereka dewasa, mereka memiliki pilihan untuk bekerja sehingga tidak rentan menjadi penganggur.

Anak penyandang thalassemia ada pula yang memiliki saudara kandung. Dengan demikian, ada anak-anak lain di rumah yang perlu juga mendapatkan perhatian dari orang tua anak penyandang thalassemia. Kakak atau adik anak penyandang thalassemia secara alamiah akan dituntut untuk dapat memahami kebutuhan dan kasih sayang anak penyandang 
thalassemia. Dengan kebutuhan perawatan yang intensif dan terus menerus dari orang tua, dan juga kemungkinan munculnya gejalagejala penyakit lain sebagai efek samping dari penggunaan obat untuk para penyandang thalassemia ini, kakak dan atau adik penyandang thalassemia dituntut orang tua dapat juga memahami keadaan orang tua dan anak penyandang thalassemia tersebut. Ini berdampak pada banyaknya perasaan terabaikan pada kakak dan atau adik penyandang thalassemia ini, dan jika perasaanperasaan ini tidak tersalurkan atau terungkapkan, maka kakak dan atau adik ini berpotensi menjadi penyebab masalah sosial, seperti misalnya berperilaku agresif ataupun sangat menarik diri.

Pasangan orang tua anak penyandang thalassemia juga memiliki perasaan-perasaan yang tidak dapat mereka ungkapkan. Diantara orang tua tidak tertutup kemungkinan ada perasaan saling menyalahkan karena dianggap sebagai penyebab anak menyandang thalassemia. Jika hal tersebut dibiarkan dan tidak diklarifikasi, maka pasangan tersebut terancam mengalami perpisahan/perceraian yang kembali akan mengakibatkan lingkaran setan permasalahan yang tidak dapat dipungkiri, diujungnya akan memunculkan masalah sosial.

Masalah-masalah tersebut menjadi tumpukan masalah tambahan di luar masalah inti, yaitu penyakit thalassemia pada anak itu sendiri. Namun begitu, tumpukan masalah tersebut sangat mempengaruhi kemampuan keluarga sebagai satu kesatuan untuk berfungsi secara sosial. Sehingga untuk mencegah agar tumpukan masalah di luar masalah utama menimbulkan masalah sosial, diperlukan pekerja sosial yang dapat mendampingi anak dan keluarganya (saudara kandung dan orang tua) mengatasi permasalahan dalam hal interaksi diantara diri mereka sendiri.

Pekerja sosial dalam setting rumah sakit berperan untuk mendampingi keluarga menguraikan satu-satu tantangan yang mereka hadapi disaat anak dan atau saudara kandung mereka didiagnosa thalassemia. Pekerja sosial bekerja dengan anak penyandang thalassemia dan keluarganya secara terpisah dan bersamasama. Secara terpisah, pekerja sosial menggali isu-isu nyata yang dihadapi setiap anggota keluarga. Kemudian, pemberian pendampingan dan pertolongan dapat diberikan secara terpisah maupun bersamasama, tergantung pada isu yang paling memerlukan pendampingan secara segera dan intensif oleh seorang pekerja sosial.

Dalam memberikan pendampingan, pekerja sosial dapat pula berperan untuk mendekatkan anak penyandang thalassemia dan keluarganya pada jaringan-jaringan yang dapat memenuhi kebutuhan mereka. Dengan menggunakan pendekatan manajemen kasus (Beder, 2006), pekerja sosial medis dapat menyediakan layanan yang komprehensif bagi anak penyandang thalassemia dan keluarganya. Untuk dapat memberikan 
layanan secara komprehensif tersebut, pekerja sosial menggunakan layanan dengan model manajemen kasus. Model manajamen kasus memungkinkan pekerja sosial untuk melakukan identifikasi kebutuhan anak penyandang thalassemia dan keluarganya, serta mengidentifikasi sumber-sumber yang tersedia untuk memenuhi kebutuhan anak dan keluarga tersebut (Gursansky, 2012). Manajemen kasus digunakan pada saat pekerja sosial berhadapan dengan klien yang memerlukan beragam layanan agar kebutuhannya dapat terpenuhi. Dubois \& Miley (2010) menyebutkan bahwa layanan pekerjaan sosial untuk kesejahteraan anak akan menggunakan manajemen kasus untuk anak penyandang thalassemia dan keluarganya karena memiliki kebutuhan yang beragam. Sementara Gursansky (2012) menyebutkan bahwa manajemen kasus cocok digunakan untuk layanan perlindungan anak.

Ada lima prinsip dalam manajemen kasus yang menjadi dasar bagi pekerja sosial dalam memberikan layanan bagi anak dan keluarganya sebagaimana yang dikemukakan oleh Kanter (2011). Kelima prinsip tersebut adalah keberlanjutan layanan; menggunakan hubungan dalam manajemen kasus; mengatur layanan sebagai respon dari kebutuhan klien; fleksibilitas strategi intervensi; dan memfasilitasi kekuatan-kekuatan atau sumbersumber yang ada pada diri klien (Kanter, 2011: 562). Sementara itu, dalam praktiknya, ada 5 tahap yang berfungsi sebagai proses inti praktik manajemen kasus, sebagaimana yang dikemukakan oleh Kanter (2011); Gursansky (2012), yaitu asesmen, perencanaan, intervensi (menghubungkan), monitoring dan evaluasi, serta transisi (advokasi).

\section{PENUTUP}

Pekerja sosial, yang berperan sebagai manajer kasus, bekerja bersama klien untuk menilai situasi yang dihadapi, meraih sumbersumber yang diperlukan serta mengawasi dan mengevaluasi pemberian pelayanan demi tercapainya kesejahteraan anak (Dubois \& Miley, 2012: 236). Dengan menggunakan model manajemen kasus, seorang pekerja sosial berperan untuk memastikan terselenggaranya program dan kegiatan yang komprehensif untuk menjawab kebutuhan klien dengan cara mengkoordinasikan layanan, menghubungkan pihak-pihak yang memberikan layanan dan mengadvokasi hakhak klien (Zastrow, 2010; Dubois \& Miley, 2010).

\section{Daftar Pustaka}

Beder, J. 2006. Hospital Social Work: The Interface of Medicine and Caring. Routledge, New York

Brown, S. \& Sessions, J.G. 1999. Education and Employment Status: a test of the strong screening hypothesis in Italy. Economics and Education Review, Pergamon. 
DuBois, B. \& Miley, K. (2010). Social Work: An Empowering Profession $6^{\text {th }} \mathrm{ed}$. Boston: Pearson Education.

Gursansky, D., Kennedy, R., \& Camilleri, P. (2012). The Practice of Case Management. Melbourne: Allen \& Unwin.

Kanter, J. (2011). Ch. 20. Clinical Case Management. Dalam J.R. Brandell (Ed), Theory and Practice in Clinical Social Work 2 ${ }^{\text {nd }}$ ed., hlm. 561-586. Thousand Oaks: Sage Publication.

Pattra Thanarattanakorn, Louthrenoo, Orawan, Sittipreechacharn, Somjai, Sanguansermsri, Torpong. 2003. Family Functioning in Children with
Thalassemia. Clinical Pediatrics; Jan/Feb 2003; 42, 1

Thackeray, M.G., Farley, O.W., \& Skidmore, R.A. 1994. Introduction to Social Work $6^{\text {th }}$ ed. Prentice Hall, New Jersey.

Zastrow, C. (2010). Introduction to Social Work and Social Welfare: Empowering People $10^{\text {th }}$ ed. California: Brooks/Cole Cengage Learning. 